\title{
HUBUNGAN PENGETAHUAN DENGAN PERILAKU PROTOKOL KESEHATAN SEBAGAI UPAYA PREVERENTIF COVID 19 PADA CIVITAS AKADEMIKA DI UNIVERSITAS MALAHAYATI BANDAR LAMPUNG
}

\author{
Eka Trismiyana ${ }^{1}$, Umi Romayati Keswara2*, A'raaf Almaera Febrian³ \\ ${ }^{1}$ Dosen Program Studi Ilmu Keperawatan Universitas Malahayati \\ E-mail : ekatrismiana@malahayati.ac.id \\ ${ }^{2}$ Dosen Program Studi IImu Keperawatan Universitas Malahayati \\ E-mail : umiromayatikeswara.76@gmail.com \\ ${ }^{3}$ Mahasiswi PSIK Universitas Malahayatl Bandar Lampung \\ E-mail : araaffebrian25@gmail.com
}

Disubmit: 01 Desember 2021 Diterima: 31 Desember 2021 Diterbitkan: 01 Januari 2022 DOI: https://doi.org/10.33024/mnj.v1i1.5565

\begin{abstract}
ATTITUDE RELATIONSHIP WITH HEALTH PROTOCOL BEHAVIOR AS A PREVERENTIVE EFFORT FOR COVID 19 IN ACADEMIC CIVITY AT MALAHAYATI UNIVERSITY BANDAR LAMPUNG
\end{abstract}

Introduction: Indonesia is showing a large number of confirmed cases and deaths in the COVID19 outbreak, and prevention strategies are needed for the more severe spread of the disease. Lampung Province the number of cases of covid 19 as of December 2020 has reached 4,871 patients who have been confirmed to have covid 19 (Lampung Provincial Health Office, 2020). As for the details of 78 new cases, namely in Bandarlampung City, 33 cases; South Lampung Regency 15 cases; East Lampung 8 cases; and North Lampung 5 cases. Then, there were 2 cases in Tulang Bawang Regency; Pringsewu 3 cases; 2 cases bid; West Coast 1 case; West Lampung 3 cases; and Central Lampung 6 cases.

Objective: To determine the relationship between attitudes and the behavior of the 5M health protocol as a pre-incentive for COVID 19 to the Academic Community at Malahayati University, Bandar Lampung in 2021

Methods: This type of research is quantitative. The design in this study used an analytical survey design with a cross sectional approach. The population in this study were all members of the community at Malahayati University, Bandar Lampung, totaling 3726 respondents. Univariate and bivariate data analysis used the chi square test.

Result : From 362 respondents who have poor category knowledge as many as 194 respondents (53.6\%), having applied category behavior as many as 228 respondents (63.0\%). The results of the chi square test obtained a p-value of 0.000 ( $\leq 0.05)$, which means that there is a relationship between knowledge and the behavior of health protocols as a preventive effort for COVID.

Suggestion: Improve campus facilities to support teaching and learning activities during the COVID-19 outbreak

Keywords : Knowledge, 3M Health Protocol Behavior, Preventive Efforts 


\section{INTISARI: HUBUNGAN PENGETAHUAN DENGAN PERILAKU PROTOKOL KESEHATAN SEBAGAI UPAYA PREVERENTIF COVID 19 PADA CIVITAS AKADEMIKA DI UNIVERSITAS MALAHAYATI BANDAR LAMPUNG TAHUN 2021}

Pendahuluan: Indonesia menunjukkan sejumlah besar kasus dan kematian yang dikonfirmasi dalam wabah COVID19, dan diperlukan strategi pencegahan untuk penyebarluasan penyakit yang lebih parah. Provinsi Lampung angka kejadian covid 19 per Desember 2020 telah menginjak angka 4.871 pasien yang terkonfirmasi mengalami covid 19 (Dinkes Provnsi Lampung, 2020) Adapun rincian 78 kasus baru yakni di Kota Bandarlampung 33 kasus; Kabupaten Lampung Selatan 15 kasus; Lampung Timur 8 kasus; dan Lampung Utara 5 kasus. Lalu, Kabupaten Tulang Bawang 2 kasus; Pringsewu 3 kasus; Pesawaran 2 kasus; Pesisir Barat 1 kasus; Lampung Barat 3 kasus; dan Lampung Tengah 6 kasus.

Tujuan: Untuk diketahui hubungan sikap dengan perilaku protokol kesehatan 5M sebagai upaya preverentif COVID 19 pada Civitas Akademika di Universitas Malahayati Bandar Lampung Tahun 2021

Metode: Jenis penelitian kuantitatif, Rancangan dalam penelitian ini menggunakan desain Survei Analitik dengan pendekatan cross sectional. Populasi dalam penelitian ini adalah seluruh civitas di Universitas Malahayati Bandar Lampung sebanyak 3726 responden. Analisa data univariat dan bivariat menggunakan uji chi square.

Hasil : Dari 362 responden yang memiliki pengetahuan kategori kurang baik sebanyak 194 responden $(53,6 \%)$, memiliki perilaku kategori menerapkan sebanyak 228 responden (63,0\%). Hasil uji chi square didapat nilai p-value 0,000 $(\leq 0,05)$ yang artinya ada hubungan pengetahuan dengan perilaku protokol kesehatan sebagai upaya preverentif COVID.

Saran : Meningkatkan fasilitas saranaprasarana kampus agar menunjang kegiatan belajar mengajar selama terdapat wabah COVID-19.

Kata Kunci

: Pengetahuan, Perilaku Protokol Kesehatan 3M, Upaya

Preverentif

\section{PENDAHULUAN}

Pravalensi COVID-19 di Indonesia cukup tinggi. Kasus yang pertama kali terkonfirmasi di Indonesia pada tanggal 2 maret 2020 dimana jumlahnya hanya dua penderita. Namun, hingga saat ini jumlahnya sudah mencapai ribuan dan menempatkan Indonesia diperingkat pertama negara terjangkit COVID-19 di wilayah Asia Tenggara. Menurut data (Listiani 2015), kasus pasien yang menderita infeksi virus corona per 18 April 2020 di Indonesia berjumlah 5.923 ribu jiwa dengan angka kematian sebanyak 520 jiwa.

Untuk Provinsi Lampung sendiri angka kejadian covid 19 per 21 Juni
2021 telah menginjak angka 21.350 pasien yang terkonfirmasi mengalami covid 19, 18544 Orang telah selesai menjalani isolasi, 1169 Orang meninggal, kasus suspek sebanyak 435 Orang dengan pembagian kasus baru 39 Orang dan kasus lama 396 Orang. Terkonfirmasi Covi 1921350 Orang, kasusus baru 159 Orang, dan kasus lama 21191 Orang (Dinkes Provnsi Lampung, 2021)

Penularan yang sangat cepat berasal dari percikan (droplets) yang berasal dari mulut, hidung penderita saat batuk, bersin atau berbicara dengan orang disekitarnya. Droplet ini masuk ke dalam saluran pernafasan hingga ke 
paru-paru lewat angiotensin converting enzyme 2 atau ACE2 yang memang banyak ditemukan pada sel alveolar tipe II paru- paru. "Virus ini menggunakan permukaannya yang berduri (spike) yang mengandung glikoprotein untuk berhubungan dengan ACE2 dan melakukan penetrasi pada sel induk (Syafrida \& Hartati, 2020; Zainaro. Et. Al. 2021).

Gejala Covid-19 dapat berupa gejala flu, yaitu demam, pilek, batuk kering, sakit tenggorokan, dan sakit kepala. Gejala ini dapat hilang atau sembuh namun dapat berkembang kepada keadaan yang lebih parah. Pada penderita dengan gejala yang parah dapat muncul demam tinggi, batuk berdahak bahkan berdarah. Bisa juga mengalami sesak nafas dan juga nyeri dada. Gejala-gejala ini merupakan akibat reaksi tubuh melawan virus ini. Secara umum, ada 3 gejala umum yang bisa menandakan seseorang terinfeksi virus covid-19 yaitu Demam di atas 38 derajat Celsius, batuk kering, sesak napas, ada beberapa gejala lain yang juga bisa muncul pada infeksi virus Corona meskipun lebih jarang seperti diare, sakit kepala, konjungtivitis, hilangnya kemampuan mengecap rasa atau mencium bau, ruam di kulit. Munculnya gejala dapat terlihat dalam kurun waktu 2 hari sampai 2 minggu setelah penderita terpapar virus Covid-19 (Satgas penanganan Covid19, 2020; WHO, 2020).

Upaya pemutusan mata rantai penyebaran covid-19 memerlukan pemahaman dan pengetahuan yang baik dari seluruh elemen termasuk masyarakat. Pengetahuan adalah suatu hasil dari rasa ingin tahu melalui proses sensoris, terutama pada mata dan telinga terhadap objek tertentu. Pengetahuan juga merupakan domain terpenting dalam terbentuknya perilaku (Donsu, 2017; Zainaro. Et al, 2021). Perilaku merupakan suatu tanggapan atau reaksi seseorang terhadap rangsangan (KBBI, 2014). Sedangkan menurut Robert Kwick dalam Donsu (2017) perilaku adalah sebagian tindakan seseorang yang dapat dipelajari dan diamati. Salah satu faktor yang mempengaruhi perilaku manusia atau masyarakat adalah tingkat pengetahuan (Donsu, 2017). Perubahan perilaku atau behavioral changes merupakan bisnis utama psikologi, yaitu dengan cara memahami perilaku melalui asesmen dan mengubah atau memodifikasinya melalui intervensi. Tentunya dalam melakukan asesmen dan intervensi, berdasarkan konsep teoretis sebagai dasar berpikir dan bertindak. (HIPMSI, 2021).

Untuk mencapai tujuan ini, langkah-langkah utama yang hendak dilaksanakan masyarakat seperti penggunaan masker; menutup mulut dan hidung saat bersin ataupun batuk; mencuci tangan secara teratur dengan sabun atau desinfeksi dengan pembersih tangan yang mengandung setidaknya $60 \%$ alkohol; menghindari kontak dengan orang yang terinfeksi; menjaga jarak dari orang-orang; dan menahan diri dari menyentuh mata, hidung, dan mulut dengan tangan yang tidak dicuci (Di Gennaro et al., 2020). Pengetahuan dan tindakan yang nyata dari pemerintah dan masyarakat terkait PHBS akan senantiasi mampu menurunkan jumlah kasus COVID-19, sehingga masa pandemi COVID-19 dapat berakhir dengan cepat.

Berdasarkan hasil prasurvey yang dilakukan wawancara bebas dan observasi terhadap 5 satpam Universitas Malahayati Bandar Lampung pada tanggal 02 Februari Tahun 2021, dengan melakukan wawancara secara bebas terpimpin 
dari ke lima satpam didapat hasil jika fenomena yang terjadi adalah, banyaknya kunjungan mahasiswa sebanyak 223, setelah itu pengunjung kampus dilakukan pemeriksaan suhu dan wajib cuci tangan, akan tetapi mahasiswa atau pengunjung kampus yang tidak menggunakan masker saat berada dalam mobil, ataupun melapas masker setelah dilakukan pemeriksaan, dengan alasan hanya sekedar menghirup udara. Kemudian petugas kebersihan yang tidak mengindahkan penggunaan masker saat bekerja, sedangkan untuk perlakuan phsycal distancing masih sering dijumpai mahasiswa yang berjalan berdekatan, dan tidak mengindahkan aturan jaga jarak.

Berdasarkan latar belakang diatas maka peneliti tertarik melakukan penelitian dengan judul "hubungan pengetahuan dengan perilaku protokol kesehatan $5 \mathrm{M}$ sebagai upaya preverentif COVID 19 pada Civitas Akademika di Universitas Malahayati Bandar Lampung Tahun 2021".

\section{METODE PENELITIAN}

Jenis penelitian menggunakan kualitatif, rancangan mengunakan survey analitik dengan pendekatan cross sectional, populasi dalam penelitian ini adalah dosen dan mahasiswa di Civitas Akademika Universitas Malahayati, dan sampel 362, teknik sampling menggunakan accidental sampling, analisa data menggunakan univariat dan bivariat menggukan uji chi square

\section{HASIL PENELITIAN DAN PEMBAHASAN Analisa Univariat}

Tabel 1

Distribusi Frekuensi Pengetahuan Tentang Protokol Kesehatan Sebagai Upaya Preverentif COVID 19 Pada Civitas Akademika Di Universitas Malahayati Bandar Lampung Tahun 2021

\begin{tabular}{|c|c|c|}
\hline Pengetahuan & Frekuensi & Persentase \\
\hline Baik & 195 & 53,9 \\
Kurang Baik & 167 & 46,1 \\
\hline Total & 362 & 100 \\
\hline
\end{tabular}

Berdasarkan tabel 1 diatas diketahui, dari 362 responden sebanyak 195 responden $(53,9 \%)$ yang memiliki pengetahuan responden terkait protokol kesehatan dengan kategori baik dan sebanyak 167 responden $(46,1 \%)$ kategori kurang baik.

Tabel 2

Distribusi Frekuensi Perilaku Tentang Protokol Kesehatan Sebagai Upaya Preverentif COVID 19 Pada Civitas Akademika Di Universitas Malahayati Bandar Lampung Tahun 2021

\begin{tabular}{|c|c|c|}
\hline Perilaku & Frekuensi & Persentase \\
\hline $\begin{array}{c}\text { Menerapkan } \\
\text { Tidak }\end{array}$ & 192 & 53,0 \\
Menerapkan & 170 & 47,0 \\
\hline Total & $\mathbf{3 6 2}$ & $\mathbf{1 0 0}$ \\
\hline
\end{tabular}


Berdasarkan tabel 2 diatas diketahui, dari 362 responden sebanyak 192 responden $(53,0 \%)$ yang memiliki perilaku responden terkait protokol kesehatan dengan kategori menerapkan dan sebanyak 170 responden $(47,0 \%)$ kategori tidak menerapkan.

\section{Analisa Bivariat}

Tabel 4.3

Hubungan Pengetahuan Dengan Perilaku Protokol Kesehatan Sebagai Upaya Preverentif COVID 19 Pada Civitas Akademika Di Universitas Malahayati Bandar Lampung Tahun 2021

\begin{tabular}{|c|c|c|c|c|c|c|c|c|}
\hline \multirow[t]{3}{*}{ Pengtahuan } & \multicolumn{4}{|c|}{ Perilaku } & \multicolumn{2}{|c|}{ Total } & \multirow{3}{*}{$\begin{array}{c}\text { - } \\
\text { Value }\end{array}$} & \multirow{3}{*}{$\begin{array}{c}\text { OR } \\
\text { CI } 95 \%\end{array}$} \\
\hline & \multicolumn{2}{|c|}{ Menerapkan } & \multicolumn{2}{|c|}{$\begin{array}{l}\text { Tidak } \\
\text { Menerapkan }\end{array}$} & & & & \\
\hline & $\mathbf{N}$ & $\%$ & $\mathbf{N}$ & $\%$ & $\mathrm{~N}$ & $\%$ & & \\
\hline Baik & 150 & 41,4 & 45 & 12,4 & $\begin{array}{r}19 \\
5\end{array}$ & 53,9 & 0,000 & $\begin{array}{c}9,921 \\
(6,121- \\
16,079)\end{array}$ \\
\hline Kurang Baik & 42 & 11,6 & 125 & 34,5 & $\begin{array}{r}16 \\
7\end{array}$ & 46,1 & & \\
\hline Total & 192 & 53,0 & 170 & 47,0 & $\begin{array}{r}36 \\
2\end{array}$ & 100 & & \\
\hline
\end{tabular}

Berdasarkan tabel 4.3 diatas diketahui, sebanyak $195 \quad(53,9 \%)$ responden yang memiliki pengetahuan baik, enerapkan perilaku protokol kesehatan dansebanyak 150 responden $(41,4 \%)$ dengan $m$ sebanyak 45 responden $(12,4 \%)$ tidak menerapkan protokol kesehatan. Sebanyak sebanyak 167 $46,1 \%$ ) responden yang memiliki pengetahuan kurang baik, sebanyak 42 responden $(11,6 \%)$ menerapkan perilaku protokol kesehatan dan sebanyak 125 responden (34,5\%) tidak menerapkan protokol kesehatan.

\section{PEMBAHASAN PENELITIAN}

Analisa Univariat

Distribusi Frekuensi Pengetahuan Tentang Protokol Kesehatan Sebagai Upaya Preverentif COVID 19 Pada Civitas Akademika Di Universitas Malahayati Bandar Lampung Tahun 2021

Dari 362 responden sebanyak 195 responden $(53,9 \%)$ yang memiliki pengetahuan responden
Hasil uji chi square didapat nilai $p$-value $0,000 \quad(\leq 0,05)$ yang artinya ada hubungan pengetahuan dengan perilaku protokol kesehatan sebagai upaya preverentif COVID 19 pada civitas akademika di Universitas Malahayati Bandar Lampung Tahun 2021. Nilai $O R=9,921) \quad$ sehingga didapat kesimpulan jika responden yang memiliki pengetahuan baik maka 9 kali berpeluang menerapkan protokol kesehatan, dibandingkan dengan responden yang memiliki pengetahuan tidak baik.

terkait protokol kesehatan dengan kategori baik dan sebanyak 167 responden $(46,1 \%)$ kategori kurang baik.

Sejalan dengan pendapat yang dikemukakan oleh Yanti (2020) Gambaran Pengetahuan Masyarakat Tentang Covid-19 Dan Perilaku Masyarakat Di Masa Pandemi Covid19. Hasil analisis mendapatkan pengetahuan masyarakat tentang 
pandemi COVID-19 ada pada kategori baik yaitu $70 \%$.

Sejalan dengan pendapat yang dikemukakan oleh Notoatmodjo (2003; Nursalam, 2018) Pengetahuan merupakan hasil dari "Tahu" dan ini terjadi setelah orang melakukan penginderaan terhadap suatu objek tertentu. Penginderaan terjadi melalui panca indra manusia, yaitu: indra penglihatan, pendengaran, penciuman, rasa dan raba. Sebagian besar pengetahuan manusia diperoleh melalui mata dan telinga, yaitu proses melihat dan mendengar. Selain itu melalui mata dan telinga yaitu proses melihat dan mendengar, selanjutnya proses pengalaman dan proses belajar dalam pendidikan formal maupun informal.

Menurut peneliti

Pengetahuan merupakan suatu unsur dalam membentuk perilaku diri seseorang. Pada dasarnya, perilaku individu ditentukan oleh pengetahuan individu itu sendiri. Pengetahuan adalah salah satu hal yang menjadi dasar untuk menangani kasus COVID-19 dalam menekan angka penularan sehingga memberikan kesadaran dalam upaya pencegahan COVID19.

Penyebaran

informasi merupakan salah satu faktor yang berpengaruh

terhadap

pengetahuan, sedangkan pengetahuan berhubungan dengan kepatuhan (Zulhafandi, 2020). Oleh karena itu, penyebaran informasi yang luas dapat mendukung tercapainya tingkat kepatuhan tinggi pelaksanaan social distancing. Pengetahuan mahasiswa terkait COVID-19 dalam menerapkan tindakan pencegahan juga disebabkan oleh beberapa faktor yang ada di dalam diri, di antaranya yaitu usia, pengalaman, minat dalam mencari informasi melalui berbagai media, ketertarikan membaca, dan lain-lain. Pengetahuan merupakan hal yang sangat penting dalam kehidupan manusia, dengan adanya pengetahuan maka seseorang dapat menentukan mana yang baik dan tidak termasuk dalam perilakunya dalam menerapkan pencegahan COVID-19.

Distribusi Frekuensi Perilaku Tentang Protokol Kesehatan Sebagai Upaya Preverentif COVID 19 Pada Civitas Akademika Di Universitas Malahayati Bandar Lampung Tahun 2021enengah Pertama Di Kecamatan Pesisir Tengah Krui Tahun 2021

Dari 362 responden sebanyak 192 responden $(53,0 \%)$ yang memiliki perilaku responden terkait protokol kesehatan dengan kategori menerapkan dan sebanyak 170 responden $(47,0 \%)$ kategori tidak menerapkan.

Sejalan dengan pendapat yang dikemukakan oleh Yanti (2020) Gambaran Pengetahuan Masyarakat Tentang Covid-19 Dan Perilaku Masyarakat Di Masa Pandemi Covid19. Hasil analisis distribusi perilaku masyakarat menunjukkan masyarakat telah mematuhi protokol kesehatan di masa pandemi COVID-19. Kategori kasus masyakarat sebagian besar ada pada kategori kasus risiko rendah (85.33\%).

Sejalan dengan teori yang dikemukakan oleh Okviana (2015) Perilaku adalah segenap manifestasi hayati individu dalam berinteraksi dengan lingkungan, mulai dari perilaku yang paling nampak sampai yang tidak tampak, dari yang dirasakan sampai paling yang tidak dirasakan.

Menurut peneliti perilaku yang didasari oleh pengetahuan akan bertahan lama dibandingkan tanpa dasar pengetahuan. Pada penelitian ini didapatkan ada beberapa mahasiswa yang memiliki 
tingkat pengetahuan tentang COVID19 sudah baik namun dalam penerapan perilaku pencegahan COVID-19 didapatkan kategori tidak menerapkan sebanyak 228 responden $(63,0 \%)$ atau tidak sesuai dengan pemahamannya tentang COVID-19. Hal ini mungkin saja terjadi karena adanya pemahaman masyarakat yang belum sama mengenai upaya pencegahan COVID19. Masyarakat tahu bahwa COVID19 merupakan penyakit yang sudah menginfeksi jutaan jiwa di seluruh dunia, namun masyarakat kurang memiliki kesadaran dan kedisiplinan dalam menerapkan upaya pencegahan COVID-19 yaitu salah satunya menaati protokol kesehatan. Kepedulian dan kesadaran masyarakat untuk melakukan upaya pencegahan COVID-19 yang masih kurang tidak hanya merugikan diri sendiri namun keluarga dan orang lain.

\section{Analisa Bivariat}

Hubungan Pengetahuan Dengan Perilaku Protokol Kesehatan Sebagai Upaya Preverentif COVID 19 Pada Civitas Akademika Di Universitas Malahayati Bandar Lampung Tahun 2021

Hasil uji chi square didapat nilai $p$-value $0,000 \quad(\leq 0,05)$ yang artinya ada hubungan pengetahuan dengan perilaku protokol kesehatan sebagai upaya preverentif COVID 19 pada civitas akademika di Universitas Malahayati Bandar Lampung Tahun 2021. Nilai $O R=9,921$ ) sehingga didapat kesimpulan jika responden yang memiliki pengetahuan baik maka 21 kali berpeluang menerapkan protokol kesehatan, dibandingkan dengan responden yang memiliki pengetahuan tidak baik.

Sejalan dengan penelitian yang dilakukan oleh Yuningsih (2020) Promosi Kesehatan Pada Kehidupan New Normal Pandemi
Covid-19. Kesiapan masyarakat menghadapi new normal tidak hanya terlihat dari aspek sosial, melainkan juga terlihat secara fisik dan mental. Fisik sehat yang senantiasa menerapkan PHBS dan protokol kesehatan serta mental yang tetap tenang dan terhindar dari gangguan kecemasan selama pandemi Covid-19 menjadi cerminan kesiapan masyarakat dalam menghadapi kehidupan new normal mendatang. Tentunya selain kesiapan masyarakat, penerapan new normal juga memerlukan kesiapan pemerintah daerah dalam segala aspek, termasuk ketersediaan fasilitas dan sumber daya kesehatan.

Sejalan dengan pendapat yang dikekmukan oleh Notoatmdjo (2010) Perilaku merupakan hasil daripada segala macam pengalaman serta interaksi manusia dengan lingkunganya yang terwujud dalam bentuk pengetahuan, sikap dan tindakan. Perilaku merupakan respon/reaksi seorang individu terhadap stimulus yang berasal dari luar maupun dari dalam dirinya.

Sebanyak $195 \quad(53,9 \%)$

responden yang memiliki pengetahuan baik, sebanyak 150 responden $(41,4 \%)$ dengan menerapkan perilaku protokol kesehatan, hal ini dapat disebabkan karena responden menerapkan informsi yang diterima dan diterapkan dalam kehidupan seharihari termasuk dalam lingkungan kampus, dan mencegah penularan virus covid 19 , sedangkan sebanyak 45 responden $(12,4 \%)$ tidak menerapkan protokol kesehatan, hal ini dapat disebabkan karena sebagain responden saat pengisian kuisioner terburu-buru dan tidak membaca dengan cermat setiap pertanyaan apakah bernilai positif ataupun negatif.

Sebanyak sebanyak 167 $46,1 \%$ ) responden yang memiliki 
pengetahuan kurang baik, sebanyak 42 responden $(11,6 \%)$ menerapkan perilaku protokol kesehatan, hal ini dikarenakan respondne memiliki perilaku yang patuh dan tetap menjalankan perintah yang telah ditetapkan oleh Universitas untuk tetapmenerapkan protokol kesehatan selama dikampus ataupun diluar kampus, sebanyak 125 responden (34,5\%) tidak menerapkan protokol kesehatan, hal ini dapat disebabkan karena mahasiswi di Universitas Malahayati tidak semua merupakan mahasiswi fakultas kesehatan, sehingga dapat memungkinkan responden tidak memahami atau kurang mematuhi peraturan yang telah diberikan oleh Universitas.

Menurut peneliti perilaku sebagai bentuk hasil dari pendidikan kesehatan dipengaruhi oleh pengetahuan dan sikap. Unsur yang sangat penting dalam membentuk tindakan seseorang dari pengalaman dan penelitian disebut sebagai pengetahuan atau kognitif. Perilaku yang berlandaskan pengetahuan akan lebih awet dari pada perilaku yang tidak dilandasi oleh pengetahuan.

Pengetahuan dapat diperoleh seseorang secara alami atau diintervensi baik langsung maupun tidak langsung. Perkembangan teori pengetahuan telah berkembang sejak lama. Filsuf pengetahuan yaitu Plato menyatakan pengetahuan sebagai "kepercayaan sejati yang dibenarkan (valid)" (justified true belief). Pengetahuan merupakan hasil dari tahu dan ini terjadi setelah orang melakukan pengindraan terhadap suatu objek tertentu. Dalam Kamus Besar Bahasa Indonesia, pengetahuan adalah sesuatu yang diketahui berkaitan dengan proses pembelajaran. Proses belajar ini dipengaruhi berbagai faktor dari dalam, seperti motivasi dan faktor luar berupa sarana informasi yang tersedia, serta keadaan sosial budaya. Pengetahuan sangat erat kaitannya dengan pendidikan di mana diharapkan seseorang dengan pendidikan tinggi akan semakin luas pula pengetahuannya. Namun, perlu ditekankan bahwa seorang yang berpendidikan rendah tidak berarti mutlak berpengetahuan rendah pula. Peningkatan pengetahuan tidak mutlak diperoleh di pendidikan formal, akan tetapi juga dapat diperoleh pada pendidikan nonformal, seperti penyuluhan yang dilakukan oleh tenaga kesehatan (Budiman dan Riyanto, 2013).

Pengetahuan merupakan domain yang sangat penting untuk terbentuknya tindakan seseorang. Pengetahuan diperlakukan sebagai dukungan dalam menumbuhkan rasa percaya diri maupun sikap dan perilaku setiap hari, sehingga dapat dikatakan bahwa pengetahuan merupakan fakta yang mendukung tindakan seseorang. Salah satu faktor yang dapat mempengaruhi kepatuhan adalah pengetahuan. Seorang warga yang mempunyai pengetahuan penggunaan protokol kesehatan yang baik, diharapkan akan menerapkan pengetahuannya dalam kepatuhan penerapan penggunaan protokol kesehatan. Antara pengetahuan, sikap, niat, dan perilaku akan mempengaruhi keikutsertaan seseorang dalam aktivitas tertentu. Adanya pengetahuan terhadap manfaat suatu hal akan menyebabkan penderita mempunyai sikap yang positif terhadap hal tersebut.

\section{KESIMPULAN}

1. Dari 362 responden didapat 195 responden $\quad(53,9 \%)$ yang memiliki pengetahuan responden terkait protokol kesehatan dengan kategori baik. 
2. Dari 362 responden sebanyak 192 responden $(53,0 \%)$ yang memiliki perilaku responden terkait protokol kesehatan dengan kategori menerapkan.

3. Hasil uji chi square didapat nilai $p$-value $0,000(\leq 0,05)$ yang artinya ada hubungan pengetahuan dengan perilaku protokol kesehatan sebagai upaya preverentif COVID 19 pada civitas akademika di Universitas Malahayati Bandar Lampung Tahun 2021.

\section{Saran}

\section{Bagi Teoritis}

1. Universitas Malahayati Bandar Lampung

Diharapkan bagi Univeristas Malahayati dapat memberikan penyuluhan kepada mahasiswa terkait penerapan protokol kesehatan selama berada dikampus, dan melakukan pembelajaran daring selama diberlakukannya PPKM di Kota Bandar Lampung.

\section{Bagi Aplikatif}

1. Mahasiswa

Malahayati

Universitas

Diharapkan bagi mahasiswa untuk selalu mematuhi protokol kesehatan yang telah ditetapkan oleh Pemerintah selama berada dilingkungan kampus, dan tetap menerapkan pola hidup bersih dan sehat baik di dalam ataupun diluar kampus.

2. Dosen Universitas Malahayati

Diharapkan bagi Dosen untuk berperan aktif mengingatkan mahasiswa melalui pesan-pesan digital via facebok, instagram, whatsapp, dan menggunakan baner ataupun leaflet yang dibagikan kepada mahasiswa baik baru ataupun lama.
3. Petugas Kesehatan Dan Keamanan Universitas

Malahayati

Diharapkan bagi petugas kesehatan untuk melakukan swab gratis bagi mahasiswa dari luar kota yang akan memasuki kampus, dan bagi petugas keamanan atau satpam dapat menegur mahasiswa yang tidak menerapkan protokol kesehatan dengan memberikan hukuman seperti pushup dan scotjum, apabila menemui mahasiswa yang tidak menggunakan masker dan menjaga jarak aman dilingkungan kampus.

4. Bagi Peneliti Selanjutnya Diharapkan peneliti selanjutnya dapat melakukan penelitian dengan menggunakan seluruh masyarakat Universitas Malahayati tanpa terkecuali yang meliputi Dosen, Mahasiswa, OB, Satpam, Bagian Keuangan, Lab, Perpustakaan, serta petugas kebersihan sebagai responden dalam penelitian ini

\section{DAFTAR PUSTAKA}

Andrews, J. L., Foulkes, L., \& Blakemore, S. J. (2020). Peer influence in adolescence: Public-health implications for COVID-19. Trends in Cognitive Sciences, 24(8), 585-587.

Budiman \& Riyanto A. (2013).

Kapita Selekta Kuisioner Pengetahuan Dan Sikap. Dalam Penelitian Kesehatan. Jakarta : Salemba Medika

Di Gennaro, F., Pizzol, D., Marotta, C., Antunes, M., Racalbuto, V., Veronese, N., \& Smith, L. (2020). Coronavirus diseases (COVID-19) current status and future perspectives: a narrative

review. International journal of environmental research 
and public health, 17(8), 2690.

Induniasih dan Wahyu Ratna. (2017). Promosi Kesehatan ; Pendidikan Kesehatan dalam Keperawatan. Yogyakarta: Pustaka Baru

Lumy, F. N., Donsu, A., \& Sambiut, F. F. (2017). Promosi Kesehatan Meningkatkan Pengetahuan Ibu Hamil Tentang HIV/AIDS. JIDAN (Jurnal Ilmiah Bidan), 5(1), 19-25.

Mansuri, F. M., Zalat, M. M., Khan, A. A., Alsaedi, E. Q., \& Ibrahim, H. M. (2020). Estimating the public response to mitigation measures and self-perceived behaviours towards the COVID-19 pandemic. Journal of Taibah University Medical Sciences, 15(4), 278-283.

Notoatmodjo, S. (2012). Metodologi Riset Keperawatan. Jakarta: Rineka Cipta.

Notoatmodjo, S. (2014). Ilmu Perilaku Kesehatan. Rineka Cipta. Jakarta.

Notoatmodjo, S. (2018). Metodologi Riset Keperawatan. Jakarta: Rineka Cipta.

Notoatmodjo, S. (2018). Promosi Kesehatan Teori Dan Aplikasi, Jakarta: Rineka Cipta.

Nurmala, I. (2020). Promosi Kesehatan. Airlangga University Press.

Nursalam. (2018). Manajemen Keperawatan: Aplikasi dalam Praktik Keperawatan Profesional. Jakarta: Salemba Medika

Syafrida, S., \& Hartati, R. (2020). Bersama melawan virus covid 19 di Indonesia. SALAM: Jurnal Sosial Dan Budaya SyarI, 7(6), 495-508.

SE Mendikbud Nomor 4 Tahun 2020 tentang Pelaksanaan
Kebijakan Pendidikan dalam Masa Darurat Penyebaran Covid-19

Usman, U., Budi, S., \& Sari, D. N. A. (2020). Pengetahuan Dan Sikap Mahasiswa Kesehatan Tentang Pencegahan Covid-19 Di Indonesia. Jurnal Ilmu Keperawatan dan Kebidanan, 11(2), 258-264.

Yanti, B., Wahyudi, E., Wahiduddin, W., Novika, R. G. H., Arina, Y. M. D. A., Martani, N. S., \& Nawan, N. (2020). Community knowledge, attitudes, and behavior towards social distancing policy as prevention transmission of COVID-19 in indonesia. Jurnal Administrasi Kesehatan Indonesia, 8(2), 4-14.

Zainaro, M. A., Andoko, A., \& Rahmawati, R. P. (2021). Hubungan Pengetahuan dan Sikap Terhadap Kejadian Covid-19 pada Masyarakat di Kelurahan Mulyojati Kota Metro. Malahayati Nursing Journal, 3(4), 517-528.

Zainaro, M. A., \& Suwares, F. M. (2021). Edukasi Masyarakat Tentang Covid-19 Di Kelurahan Negeri Jaya Kecamatan Negeri Besar Kabupaten Way Kanan. JURNAL KREATIVITAS PENGABDIAN KEPADA MASYARAKAT (PKM), 4(6), 1514-1518. 